\title{
PENGARUH KEPEMIMPINAN DAN KOMITMEN ORGANISASI TERHADAP MOTIVASI DAN KINERJA DOSEN UNIVERSITAS ISLAM NEGERI SULTAN SYARIF KASIM RIAU
}

\author{
Andri Yanto ${ }^{1}$, Sri Indarti ${ }^{2}$, Yusni Maulida ${ }^{3}$ \\ Universitas Riau \\ andriyanto0014@gmail.com, sri_indarti_fe@yahoo.com, aw_131105@yahoo.com
}

\begin{abstract}
Education is a tool for a nation to create quality humans. Improving the quality of education needs to be improved, among others, by increasing the efficiency of education management, appropriate learning methods and the performance of educators. This study aims to determine the effect of leadership, organizational commitment on motivation and performance. The population in this study was a lecturer at UINSultan Syarif Kasim. The sample in this study were 242 people who were obtained using the Slovin formula calculation. Sampling using stratified random sampling method. The data collection technique used a questionnaire with a Likert scale. Data analysis techniques with path analysis using SPSS 25 software. The results showed that leadership and commitment had a positive and significant effect on motivation. Leadership and commitment have a positive and significant effect on lecturer performance. Motivation has a positive and significant effect on lecturer performance. Leadership has a positive and significant effect on lecturer performance through motivation. Commitment has a positive and significant effect on lecturer performance through motivation.
\end{abstract}

Keywords: Leadership and Organizational Commitment to Lecturer Motivation and Performance

\begin{abstract}
ABSTRAK
Pendidikan merupakan alat bagi suatu bangsa untuk menciptakan manusia yang berkualitas. Peningkatan mutu pendidikan perlu di tingkatkan diantaranya dengan meningkatkan efisiensi manajemen pendidikan, metode pembelajaran yang tepat dan kinerja tenaga pendidik. Penelitian ini bertujuan untuk mengetahui pengaruh kepemimpinan, komitmen organisasi terhadap motivasi dan kinerja. Populasi dalam penelitian ini adalah Dosen UINSultan Syarif Kasim. Sampel dalam penelitian ini sebanyak 242 orang yang diperoleh menggunakan pperhitungan rumus slovin. Pengambilan sampel menggunakan metode stratified random sampling. Teknik pengumpulan data menggunakan kuisioner dengan skala likert. Teknik analisis data dengan path analysis menggunakan bantuan softwere SPSS versi 25. Hasil penelitian menunjukkan kepemimpinan dan komitmen berpengaruh positif dan signifikan terhadap motivasi. Kepemimpinan dan komitmen berpengaruh positif dan signifikan terhadap kinerja dosen. Motivasi berpengaruh positif dan signifikan terhadap kinerja dosen. Kepemimpinan berpengaruh positif dan signifikan terhadap kinerja dosen melalui motivasi. Komitmen berpengaruh positif dan signifikan terhadap kinerja dosen melalui motivasi.
\end{abstract}

Kata Kunci: Kepemimpinan Dan Komitmen Organisasi Terhadap Motivasi Dan Kinerja Dosen 


\section{PENDAHULUAN}

Pendidikan merupakan satu diantara faktor yang menentukkan kemajuan suatu bangsa. Majunya suatu negara sangat ditentukan oleh kualitas sumber daya manusia yang berkualitas. Dalam mengahasilkan sumber daya manuia berkuliatas dapat tempuh dengan penyelenggaraan pendidikan yang bermutu. Laporan lebaga pemeringkatan internasional Webometrics yang kedudukan di Spanyol ditahun 2020 merilis hanya ada dua universitas Indonesia yang bertengger di top 1000 perguruan tinggi terbaik di dunia. (https://lldikti5.kemdikbud.go.id). Universitas Indonesia (UI) menurut lembaga tersebut menduduki peringgat 693 sementara Institut Teknologi Bandung (ITB) berada pada peringkat 891 dunia.

Sebagaimana universitas lainnya di Indonesia, Universitas Islam Negeri Sultan Syarif Kasim Riau Riau (UIN Suska Riau) juga memiliki tujuan yang ingin dicapainya, diantaranya adalah menghasilkan lulusan yang unggul dalam bidang akadmik, berakhlak mulia, mengembangkan, menciptakan ilmu pengetahuan, teknologi, dan/atau seni yang bernafaskan Islam. Oleh karena itu untuk mencapai tujuan yang telah ditetapkan, maka pihak universitas harus mampu untuk memanfaatkan seluruh potensi yang dimilikinya, mulai dari teknologi, maupun sumber daya manusia yang dimilikinya.

Salah satu yang menjadi penggerak utama pendidikan tinggi adalah tenaga pendidik, dalam hal ini adalah dosen. Dalam UU No.12 tahun 2012 dinyatakan Dosen adalah tenaga pendidik pada perguruan tinggi yang khususnya diangkat dengan tujuan mengajar. Dosen merupakan komponen penting dalam sistim pendidikan di indonesia. tugas, tanggung jawab dan kinerja mereka akan sangat mennetukan tujuan pendidikan nasional dalam upaya mencerdaskan kehidupan bangsa.

Menurut (Smith, 2002) kinerja merupakan hasil yang didapat dari suatu proses yang dikerjakan. Menurut (Trisnaningsih, 2011) kinerja dosen merupakan kemampuan yang dimiliki seorang dosen untuk memlakukan pekerjaan atau tuagas yang sdibebankan. Dosen dalam melaksanakan pekerjaannya diikat oleh tri dharma perguruan tinggi sebagimana yang diatur dalam Undang-undang nomor 20 Tahun 2003 tentang sistem pendidikan nasional (Indonesia, 2003), Peratusan pemerintah nomor 37 tahun 2009 tentang dosen, yang 
menerangkan bahwa termasuk kedalam tugas pokok Dosen adalah Dharma pendidikan, Dharma penelitian dan Dharma pengabdian masyarakat.

Syarif (2013:86) menyatakan bahwa kunci utama untuk meningkatkan mutu pendidikan tinggi ialah lembaga/pimpinan harus meningkatkan mutu dosen yang memiliki motivasi tinggi untuk memajukan perguruan tinggi tempatnya bekerja, memiliki kepemimpinan di bidangnya, dan memiliki komitmen yang tinggi terhadap institusinya. Motivasi merupakan suatu keinginan seseorang bekerja untuk mencapai suatu tujuan, di mana keinginan tersebut dapat mendorong anggota untuk melakukan pekerjaan atau dapat mengakibatkan timbulnya mobilitas kerja. (Robbins \& Coulter, 2014) menggambarkan jika motivasi merupakan proses yang dilakukan seseorang dalam upaya memberikan energi, diarahkan dan dipertahankan untuk mencapai tujuan.

Selain motivasi, faktor yang dapat mempengaruhi kinerja adalah komitmen organisasi. Komitmen organisasi dalam hal ini adalah suatu keterkaitan antara diri dan tugas yang diemban seorang dosen agar dapat melahirkan tanggung jawab yang dapat mengarahkan serta membimbing dalam kegiatan pembelajaran. Komitmen dosen yang tinggi sangat diperlukan dalam sebuah organisasi pendidikan tinggi, karena terciptanya komitmen yang tinggi akan mempengaruhi situasi kerja yang profesional. Salah satu aspek dari komitmen adalah keinginan bekerja keras. Berikut disajikan laporan kinerja kenaikan pangkat dosen dilingkunagn UIN sultan syarif kasim Riau.

Tabel 1. Data Dosen Universitas Islam Negeri Sultan Syarif Kasim Riau yang Tidak Naik Pangkat Per-Tahun 2019

\begin{tabular}{lcccc}
\hline \multirow{2}{*}{ Jabatan Fungsional } & Jumlah & \multicolumn{4}{c}{ Rentang Tahun (Orang) } \\
\cline { 3 - 5 } & $\begin{array}{c}\text { Dosen } \\
\text { (Orang) }\end{array}$ & $2-5$ Tahun 6-10 Tahun & >10 Tahun \\
\hline Guru Besar (IV/d) & 12 & 1 & 10 & 1 \\
\hline Lektor Kepala (IV/c) & 15 & 4 & 9 & 2 \\
\hline Lektor Kepala (IV/b) & 26 & 4 & 16 & 6 \\
\hline Lektor Kepala (IV/a) & 51 & 17 & 19 & 15 \\
\hline Lektor (III/d) & 147 & 86 & 47 & 14 \\
\hline Lektor (III/c) & 80 & 21 & 42 & 17 \\
\hline Assisten Ahli (III/b) & 27 & 5 & 18 & 4 \\
\hline Jumlah & 358 & 138 & 161 & 59 \\
\hline
\end{tabular}

Sumber : Akademik UIN Sultan Syarif Kasim Riau, 2020 
Dari tabel diatas dapat dijelaskan bahwa sebagian besar dosen masih kurang termotivasi dalam hal kepengurusan pangkat mereka, ini terlihat dari banyaknya dosen yang belum mengurus kenaikan pangkat bahkan lebih dari 10 tahun. Indikasi lain juga mengungkapkan bahwa kurangnya minat dosen dalam meneliti dan melakukan kegiatan pengabdian kepada masyarakat yang merupakan salah satu syarat administrasi kenaikan pangkat. Tentu hal ini sangat disayangkan, karena sebagian besar dosen tersebut memiliki jabatan fungsional setingkat Lektor, Lektor Kepala bahkan Guru Besar.

Selain motivasi dan komitmen organisasi, faktor yang dapat mempengaruhi kinerja adalah kepemimpinan. Pemimpin yang baik adalah seorang pemimpin yang mampu membangkitkan semangat kerja dan menanamkan rasa percaya diri serta tanggung jawab. Kepemimpinan melibatkan hubungan yang mendalam antara orang-orang yang menginginkan perubahan signifikan, dan perubahan tersebut mencerminkan tujuan yang dimiliki bersama oleh pemimpin dan pengikutnya (Safaria, 2010:3).

Penelitian yang menyoroti tentang variabel yang berperan dalam upaya meningkatkan kinerja sudah banyak dijelaskan. Banyak juga diantara penelitian tersebut yang menghasilkan kesenjangan penelitian. Penelitian yang itu dantaranya yang menyoal pengaruh motibvasi terhdap kinerja yang dilakukan (Kasim, Rantetampang, \& Lumbantobing, 2016), serta (Siagian, 2018) yang menemukan bahwa motivasi kerja memberikan hasil poitif terhadap kinerja. Sementara itu penelitian Dhermawan (2012) dan Prananta (2008) menunjukkan hasil sebaliknya, bahwa motivasi tidak berpengaruh terhadap kinerja.

Berdasarkan latar belakang masalah dan fenomena yang sudah diuraikan di atas, maka melalui pendekatan manajemen sumber daya manusia, penulis tertarik untuk melakukan penelitian tentang "Pengaruh Kepemimpinan dan Komitmen Organisasi Terhadap Motivasi Dan Kinerja Dosen Universitas Islam Negeri Sultan Syarif Kasim Riau”.

\section{TINJAUAN LITERATUR}

\section{Kinerja}

Menurut Emron, Yohny dan Imas $(2017 ; 190)$ kinerja merupakan hasil dari suatu proses yang mengacu dan diukur selama periode waktu tertentu berdasarkan ketentuan atau kesepakatan yang telah ditetapkan sebelumnya. Menurut Priansa (2016;269) kinerja merupakan tingkat keberhasilan pegawai dalam menyelesaikan pekerjaannya, perwujudan dari kemampuan dalam bentuk karya nyata dan hasil kerja yang dicapai pegawai dalam 
mengemban tugas dan pekerjaan yang berasal dari organisasi. Menurut Amir (2015;83) kinerja pegawai adalah perilaku atau kegiatan yang ditampilkan oleh sesorang dalam kaitannya dengan tugas kerja di perusahaan, departemen, atau organisasi, dilaksanakan sesuai dengan potensi yang dimilikinya, dalam rangka menghasilkan sesuatu yang bermakna bagi organisasi, masyarakat luas, atau bagi dirinya sendiri.

Wibowo (2014) menyatakan kinerja adalah tentang melakukan pekerjaan dan hasil yang dicapai dari pekerjaan tersebut. Kinerja juga merupakan apa yang diharapkan dan bagaimana cara mengerjakannya. Menurut Kasmir (2016:182) mendefenisikan kinerja merupakan hasil kerja atau perilaku kerja yang telah dicapai dalam menyelesaikan tugas-tugas dan tanggungjawab yang diberikan dalam suatu periode tertentu. Penilaian kinerja biasanya dilakukan pihak manajemen untuk satu atau beberapa periode tertentu. Hasibuan (2011:94) mengemukakan bahwa kinerja adalah suatu hasil kerja yang dicapai seseorang dalam melaksanakan tugas-tugas yang dibebankan kepadanya yang didasarkan atas kecakapan pengalaman dan kesungguhan serta waktu.

Dari berbagai pendapat diatas, maka dapat ditarik kesimpulan, kinerja adalah hasil kerja yang dicapai oleh seseorang baik kualitas maupun kuantitas pada periode waktu pelaksanaan pekerjaan yang telah ditentukan.

\section{Motivasi}

Menurut Wibowo (2014:111) motivasi merupakan dorongan untuk bertindak terhadap serangkaian proses perilaku manusia dengan mempertimbangkan arah, intensitas, dan ketekunan pada pencapaian tujuan. Motivasi menurut Sutrisno (2014:146) motivasi adalah suatu faktor yang mendorong seseorang untuk melakukan suatu aktivitas tertentu, oleh karena itu motivasi sering kali diartikan pula sebagai faktor pendorong perilaku seseorang. Setiap aktivitas yang dilakukan oleh seseorang pasti memiliki suatu faktor yang mendorong aktivitas tersebut.

Menurut Simanjuntak (2012:11) suatu determinasi penting dari kinerja individu adalah motivasi. Namun motivasi bukanlah satu satunya determinasi, variabel - variabel lain seperti usaha yang diberikan, kemampuan, pengalaman juga mempengaruhi kinerja. Dari pernyataan tersebut, dapat dikatakan bahwa kinerja dipengaruhi oleh motivasi. dengan adanya motivasi, maka terjadilah kemauan kerja dan dengan adanya kemauan maka kinerja akan meningkat.

\section{Kepemimpinan}


Pemimpin dan kepemimpinan memiliki definisi yang berbeda. Pemimpin merupakan individunya, sedangkan kepemimpinan merupakan pola tindakan dan tingkah laku dari pemimpin tersebut. Menurut Emron, dkk (2017:87) kepemimpinan adalah proses mempengaruhi orang lain untuk memahami dan setuju dengan apa yang perlu dilakukan dan bagaimana tugas itu dilakukan secara efektif, serta proses memfasilitasi upaya individu dan kolektif untuk mencapai tujuan. Menurut Kartono (2009:10), pemimpin merupakan inisiator, motivator, stimulator, dinamisator, dan inovator dalam organisasi. Menurut Dubrin (2009:4) pemimpin ialah seseorang yang dapat menunjukkan semangat, hasrat, dan memberi inspirasi bagi orang lain agar mencapai kinerja yang lebih baik (bekerja keras) dan menaikkan laba. Kepemimpinan adalah kemampuan untuk menciptakan rasa percaya diri dan dukungan diantara bawahan agar tujuan organisasi dapat tercapai.

Kepemimpinan adalah proses kerjasama diantara manusia untuk mencapai tujuan, sebagai suatu bentuk energi yang memotori setiap usaha bersama, yang memberikan model untuk diteladani, yang memotivasi, yang menimbulkan semangat kerja, dan yang mempercayai bawahan untuk mengendalikan diri sendiri (Dharma, 2009:136).

\section{Komitmen Organisasi}

Meyer dan Herscovitch $(2010 ; 301)$ menyatakan bahwa komitmen organisasi adalah kekuatan yang mengikat seorang individu untuk suatu tindakan yang relevan dengan satu atau beberapa tujuan. Luthans $(2010 ; 217)$ mendefinisikan bahwa komitmen organisasi adalah sikap yang mencerminkan loyalitas Dosen terhadap organisasi mereka dan proses yang berkelanjutan dimana peserta organisasi mengeksresikan kepedulian mereka terhadap organisasi, kesuksesan dan kesejahteraan. Menurut Sutrisno (2011:296) komitmen Dosen merupakan sikap loyalitas pekerja terhadap organisasi dan juga merupakan suatu proses mengekspresikan perhatian dan partisipasinya terhadap organisasi.

Dari beberapa definisi tersebut dapat disimpulkan bahwa komitmen organisasi organisasi adalah seberapa loyal seorang Dosen terhadap organisasinya, yang ditunjukkan dengan adanya keinginan untuk bekerja maksimal, memiliki keyakinan terhadap kemajuan organisasi, kesediaan untuk tetap menerima nilai-nilai bersama, dan penerimaan terhadap apa yang menjadi tujuan organisasi.

\section{METODE PENELITIAN}


Penelitian ini dilakukan di Universitas Islam Negeri Sultan Syarif Kasim. Waktu penelitian dilaksanakan pada bulan Agustus 2020. Penelitain ini menggunakan pendekatan kuantitaif dalam menjawab secara empiris setiap fenomena yang digambarkan kedalam variabel terkait. Jenis data yang diperlukan dalam pada penelitian ini adalah data primer dan sekunder berupa tanggapan responden yang terekam dalam hasil kuesioner. Populasi dalam penelitian ini adalah seluruh dosen yang tercatat di Universitas Islam Negeri Sultan Syarif Kasim Riau yaitu sebanyak 609 orang. Penentuan sampel dalam penelitian ini menggunakan rumus Slovin, dengan sampel sebanyak 242 orang dosen. Pengambilan sampel menggunakan metode stratified random sampling dengan tujuan agar seluruh fakultas punya perwakilan dari setiap sampel yang sudah di tentukan. Pengumpulan data dengan penyebaran kuesioner menggunakan skala likert. Pengolahan data dilakukan dengan melakukan uji instrumen, uji asumsi klasik, dan uji analisis jalur (path analysis). penelitian ini menggunakan bantuan softwere SPSS versi 25.

\section{HASIL DAN PEMBAHASAN}

\section{Hasil Penelitian}

Uji Validitas dan Reliabilitas

Uji Validitas (Validity) Kuesioner

Hasil perhitungan kuesioner variabel penelitian dengan kriteria yang digunakan item valid apabila nilai korelasinya lebih besar atau sama dengan nilai $r$ tabel. $r$ tabel diperoleh dengan menggunakan rumus $\mathrm{df}=\mathrm{n}-2=242-2=240$, sehingga diperoleh nilai $\mathrm{r}$ tabel sebesar 0,138 .

\section{Uji Reliabilitas (reliability)}

Instrument dinyatakan reliable jika nilai koefisien cronbach alpha $>0.60$. Dari hasil perhitungan uji reliabilitas dengan menggunakan program SPSS Versi 25

maka dapat dinyatakan bahwa alat ukur yang digunakan dalam penelitian ini telah menunjukan data yang reliabel dan dapat digunakan sebagai alat untuk variabel penelitian.

\section{Uji Normalitas Data}

Uji normalitas ini dilakukan untuk menguji apakah model regresi, variabel dependen dan variabel independen mempunyai distribusi normal atau tidak. Model regresi yang baik adalah memiliki distribusi normal. Untuk lebih jelasnya hasil uji normalitas data dapat dilihat pada Tabel berikut. 
Tabel 2 Uji Normalitas Kolmogrov Smirnov

\begin{tabular}{clcl}
\hline No & Uji Normalitas & Asym.Sig & Ket \\
\hline 1 & Persamaan 1 & 0,110 & Normal \\
\hline 2 & Persamaan 2 & 0,240 & Normal \\
\hline
\end{tabular}

Sumber: data olahan, 2020

Tabel 2 memperlihatkan bahwa dari hasil uji normalitas kolmogrov smirnov, terlihat bahwa baik itu persaman 1 maupun persamaan 2 memiliki nilai sig lebih besar dari nilai alpha sebesar 0.05 , yang berarti data telah berdistribusi normal. Dari hasil tersebut dapat diketahui bahwa data penelitian ini telah berdistribusi normal.

\section{Uji Hipotesisi}

\section{Analisis Jalur (Path Analysis)}

Pengujian hipotesis yang dilakukan dalam penelitian ini menggunakan analisis jalur. Pengujian hipotesis dilakukan berdasarkan angket yang telah disebarkan kepada responden sebanyak 242 orang.

\section{Persamaan Struktual 1}

Persamaan Struktural 1 diuji dengan menggunakan uji secara simultan, individual dan koefisien determinasi $\left(\mathrm{r}^{2}\right)$. Untuk lebih jelasnya dapat dilihat pada uraian berikut :

\section{Uji Simultan (Uji F)}

Uji secara bersama-sama (simultan) digunakan untuk mengetahui pengaruh variabel komitmen (X1), kepemimpinan (X2) secara bersama-sama terhadap motivasi (Y1). Sebelum dilakukan penelitian, maka untuk membandingkan nilai f hitung dengan f Tabel, maka nilai $\mathrm{f}_{\text {tabel }}$ pada taraf signifikansi $5 \%$ diperoleh dengan persamaan $\mathrm{f}_{\text {tabel }}=\mathrm{n}-\mathrm{k}-1 ; \mathrm{k}, 242-2-1 ; 239$ yang mana didapat angka sebesar 3.04. Hasil analisa statistik uji f dapat dilihat pada tabel berikut:

Tabel 3 Hasil Uji Simultan Struktur 1

\begin{tabular}{ccccc}
\hline Model & Variabel & Fhitung & Ftabel & Sig \\
\hline 1 & Kepemimpinan, Komitmen & 43,871 & 3,04 & 0,000 \\
\hline
\end{tabular}

Sumber: data olahan, 2020

Tabel 3 memperlihatkan Hasil uji signifikansi secara bersama-sama menunjukan nilai $\mathrm{f}_{\text {hitung }}=43,871>\mathrm{f}_{\text {tabel }}=3,04$ dan nilai sig $=0,000<0,05$, artinya variabel komitmen dan kepemimpinan, berpengaruh secara bersama-sama dan signifikan terhadap variabel motivasi. 
Hasil analisa statistik uji t dapat dilihat pada tabel berikut:

Tabel 4 Hasil Uji Parsial Struktur 1

\begin{tabular}{clcccc}
\hline No. & Variabel & Koefisien Path & thitung & Ttabel & Sig \\
\hline 1 & Kepemimpinan & 0,363 & 6,251 & 1,987 & 0,000 \\
\hline 2 & Komitmen & 0,274 & 4,716 & 1,987 & 0,000 \\
\hline
\end{tabular}

Sumber : data olahan, 2020

Dari Tabel 4 dapat dilihat bahwa hasil pengujian secara individual antara variable komitmen dan kepemimpinan terhadap motivasi. Untuk lebih jelasnya dapat dilihat pada uraian berikut:

\section{Pengaruh Kepemimpinan Terhadap Motivasi}

Penelitian ini memperlihatkan bahwa terdapat pengaruh yang signifikan antara kepemimpinan terhadap motivasi. Hal ini dibuktikan melalui nilai koefisien jalur 0,349 dan nilai t hitung sebesar 6,251 > dari t tabel sebesar 1,987 serta nilai signifikansi yang kurang dari $0,05(\mathrm{a}=5 \%)$ yaitu sebesar $0.000<0,05$. Dapat diartikan bahwa kepemimpinan berpengaruh positif dan signifikan terhadap motivasi. Jadi hasil ini menyatakan bahwa kepemimpinan berpengaruh terhadap motivasi dapat diterima.

\section{Pengaruh Komitmen Terhadap Motivasi}

Hasil penelitian ini memperlihatkan bahwa terdapat pengaruh yang signifikan antara komitmen terhadap motivasi. Hal ini dibuktikan melalui nilai koefisien jalur 0,274 dan nilai $\mathrm{t}$ hitung sebesar 4,716> dari t tabel sebesar 1,987 serta nilai signifikansi yang kurang dari 0,05 $(a=5 \%)$ yaitu sebesar $0.000<0,05$. Dapat diartikan bahwa komitmen berpengaruh positif dan signifikan terhadap motivasi. Jadi hasil ini menyatakan bahwa komitmen berpengaruh terhadap motivasi dapat diterima.

Untuk lebih jelasnya dapat dilihat pada diagram jalur untuk persamaan struktural 1 dapat dilihat pada gambar berikut ini:

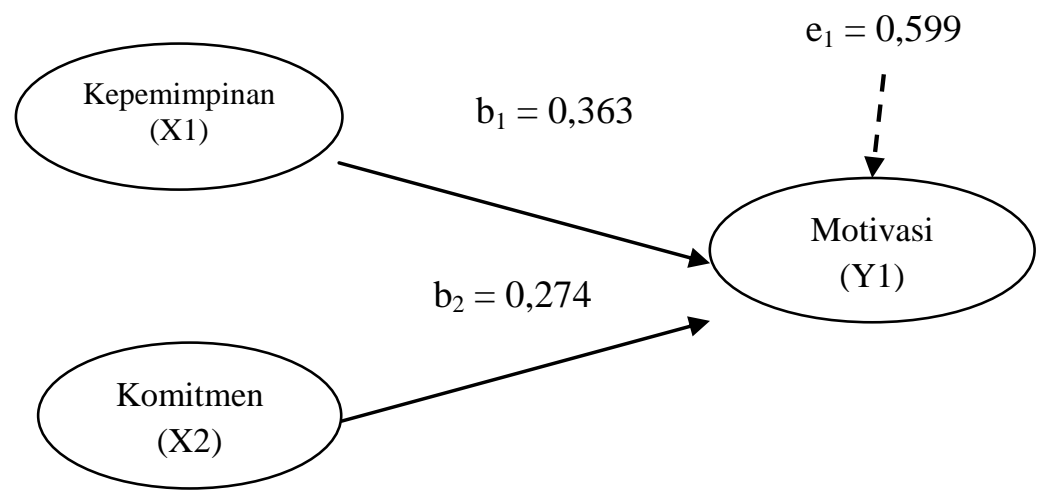


Sumber : data olahan, 2020

\section{Persamaan Struktural 2}

Persamaan Struktural 2 akan mendapatkan pengaruh secara bersama-sama (Uji F), pengaruh secara individual (uji t) dan koefisien determinasi $\left(\mathrm{R}^{2}\right)$.

\section{Uji Simultan (Uji F)}

Uji secara bersama-sama (simultan) digunakan untuk mengetahui pengaruh variabel Komitmen, Kepemimpinan dan Motivasi terhadap Kinerja Dosen. Hasil analisa statistik uji F dapat dilihat pada tabel berikut:

Tabel 5 Hasil Uji Simultan Struktur 2

\begin{tabular}{ccccc}
\hline Model & Variabel & Fhitung & Ftabel & Sig \\
\hline 1 & Kepemimpinan, Komitmen, Motivasi & 44,478 & 2,64 & 0,000 \\
\hline
\end{tabular}

Sumber: data olahan, 2020

Dari Tabel 5 diperoleh hasil penelitian dengan nilai $\mathrm{f}_{\text {hitung }}=44,478$ dan nilai sig $=$ 0,000, yang mana nilai f hitung lebih besar dari nilai f Tabel sebesar 2,64 dan nilai sig $=0,000$ $<0,05$, artinya variabel komitmen, kepemimpinan, dan motivasi secara bersama-sama berpengaruh dan signifikan terhadap variabel kinerja dosen.

\section{Uji Signifikan Secara Individual (Uji t)}

Persamaan Struktural $2\left(\mathrm{Y} 2=\mathrm{bX}_{1}+\mathrm{bX}_{2}+\mathrm{bY}_{1}+\mathrm{e}\right)$. hasil perhitungan pengaruh dapat dilihat pada Tabel 6.

Tabel 6 Hasil Uji Parsial Model 2

\begin{tabular}{clcccc}
\hline No. & Variabel & Koefisien Path & thitung & Ttabel & Sig \\
\hline 1 & Kepemimpinan & 0,187 & 3,185 & 1,987 & 0,002 \\
\hline 2 & Komitmen & 0,208 & 3,655 & 1,987 & 0,000 \\
\hline 3 & Motivasi & 0,370 & 6,105 & 1,987 & 0,000 \\
\hline
\end{tabular}

Sumber: data olahan, 2020

\section{Pengaruh Kepemimpinan Terhadap Kinerja Dosen}

Dari Tabel 6 diperoleh nilai koefisien jalur 0,187 dan nilai t hitung sebesar 3,185 > dari t tabel sebesar 1,987 serta nilai signifikansi yang kurang dari 0,05 $(a=5 \%)$ yaitu sebesar $0.002<0,05$. Dapat diartikan bahwa kepemimpinan berpengaruh positif dan signifikan terhadap kinerja dosen. Hasil ini menyatakan bahwa kepemimpinan berpengaruh terhadap kinerja dosen dapat diterima. 
Tabel 6 memperlihatkan nilai koefisien jalur 0,208 dan nilai t hitung sebesar 3,655 > dari t tabel sebesar 1,987 serta nilai signifikansi yang kurang dari 0,05 $(a=5 \%)$ yaitu sebesar $0.000<0,05$. Dapat diartikan bahwa komitmen berpengaruh positif dan signifikan terhadap kinerja dosen.

\section{Pengaruh Motivasi Terhadap Kinerja Dosen}

Berdasarkan Tabel 6 nilai koefisien jalur variable motivasi sebesar 0,370 dan nilai $\mathrm{t}$ hitung sebesar 6,105> dari t tabel sebesar 1,987 serta nilai signifikansi yang kurang dari 0,05 $(a=5 \%)$ yaitu sebesar $0.000<0,05$. Dapat diartikan bahwa motivasi berpengaruh positif dan signifikan terhadap kinerja dosen. Artinya bahwa motivasi berpengaruh terhadap kinerja dosen dapat diterima. Untuk persamaan struktural 2 dapat dilihat pada gambar berikut ini:

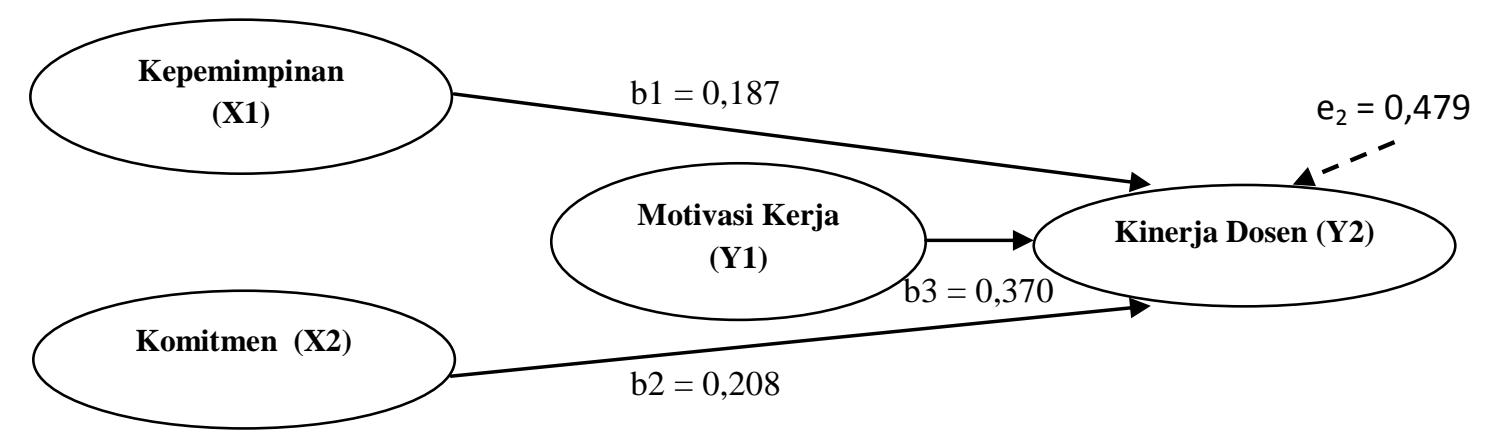

\section{Uji Sobelt test}

Sumber : data olahan, 2020

Uji sobel test dalam penelitian ini adalah bertujuan untuk mengetahui pengaruh tidak langsung antara variable komitmen dan kepemimpinan terhadap kinerja dosen melalui motivasi. Untuk lebih jelasnya dapat dilihat pada uraian berikut:

\section{Pengaruh Kepemimpinan terhadap Kinerja Dosen melalui Motivasi}

Berdasarkan Gambar 4.1 dan 4.2 koefisien jalur untuk variabel kepemimpinan terhadap motivasi sebesar 0.363 sedangkan untuk motivasi terhadap kinerja dosen sebesar 0.370. Pengaruh tidak langsung kepemimpinan terhadap kinerja dosen melalui motivasi mempunyai nilai koefisien jalur sebesar 0.134 (0.363 x 0.370), sedangkan pengaruh langsung kepemimpinan terhadap kinerja dosen sebesar 0.187. Hasil uji sobelt test dari pengaruh mediasi oleh variabel intervening motivasi adalah sebagai berikut:

Tabel 7 Uji Sobelt Pengaruh Tidak Langsung 1

\begin{tabular}{ccccc}
\hline Variabel & Koefisien Path & thitung & Ttabel & Sig \\
\hline Kepemimpinan-Motivasi-Kinerja & 0,134 & 2,540 & 1,987 & 0,005 \\
\hline
\end{tabular}


Sumber : data olahan, 2020

Dari hasil uji Sobel test menunjukkan t hitung $=2,540>$ dari t tabel $=1,987$, dan nilai signifikan sebesar $0,005<0,05$ sehingga disimpulkan bahwa terdapat pengaruh yang signifikan antara kepemimpinan terhadap kinerja dosen melalui motivasi

\section{Pengaruh Komitmen terhadap Kinerja Dosen melalui Motivasi}

Hasil perhitungan koefisien jalur variabel komitmen terhadap motivasi sebesar 0.274 sedangkan motivasi terhadap kinerja dosen sebesar 0.370. Pengaruh tidak langsung komitmen terhadap kinerja dosen melalui motivasi sebagai variabel intervening mempunyai nilai koefisien jalur sebesar 0.101 (0.274 x 0.370), sedangkan pengaruh langsung komitmen terhadap kinerja dosen sebesar 0.208. Adapun hasil uji sobelt test dari pengaruh mediasi oleh variabel intervening motivasi adalah sebagai berikut:

Tabel 8 Uji Sobelt Pengaruh Tidak Langsung 2

\begin{tabular}{lcccc}
\hline Variabel & Koefisien Path & thitung & Ttabel & Sig \\
\hline Komitmen-Motivasi-Kinerja & 0,101 & 2,989 & 1,987 & 0,001 \\
\hline
\end{tabular}

Sumber : data olahan, 2020

Dari hasil uji sobel test menunjukkan $t$ hitung $=2,989>$ dari $t$ tabel $=1,987$ dan nilai signifikan sebesar $0.001<0,05$ sehingga disimpulkan bahwa terdapat pengaruh yang signifikan antara komitmen terhadap kinerja dosen melalui motivasi.

\section{KESIMPULAN}

Berdasarkan hasil penelitian yang diperoleh dan pembahasan yang telah di kemukakan pada penjelasan sebelumnya, maka beberapa yang menjadi kesimpulan dari penelitian ini adalah sebagai berikut: (1) Kepemimpinan berpengaruh positif dan signifikan terhadap motivasi. (2) Komitmen berpengaruh positif dan signifikan terhadap motivasi. Artinya setia seorang yang mengutamakan kepentingan organisasi, memberikan suatu dorongan atau motivasi kepada dosen untuk bekerja secara optimal. Hal ini berarti semakin baik komitmen maka motivasi akan meningkat. (3) Kepemimpinan berpengaruh positif dan signifikan terhadap kinerja dosen. Artinya semakin baik kepemimpinan maka kinerja dosen akan meningkat.

Selain itu penelitain ini juga memnuktikan bahwa (4) Komitmen berpengaruh positif dan signifikan terhadap kinerja dosen. Artinya setia seorang yang mengutamakan kepentingan 
organisasi, maka akan mengerjakan tugas yang sesuai dengan bidang pendidikan dan pengajaran lebih cepat. (5) Motivasi berpengaruh positif dan signifikan terhadap kinerja dosen, semakin tinggi tingkat motivasi, maka kinerja dosen akan meningkat. (6) Kepemimpinan berpengaruh positif dan signifikan terhadap kinerja dosen melalui motivasi, artinya kepemimpinan yang baik diikuti dengan motivasi, maka kinerja dosen akan meningkat. (7) Komitmen berpengaruh positif dan signifikan terhadap kinerja dosen melalui motivasi. Hal ini menunjukkan komitmen yang baik diikuti dengan motivasi yang baik juga maka akan meningkatkan kinerja dosen. 


\section{DAFTAR PUSTAKA}

Amir, Mohammad Faisal, 2015. Memahami Evaluasi Kinerja Karyawan, Konsep, dan Penilaian Kinerja di Perusahaan. Jakarta:Penerbit Mitra Wacana Media.

Dharma, Agus, 2013. Manajemen Supervisi : Petunjuk Praktis Bagi ParaSupervisor. Jakarta, Raja Grafindo Persada

Dhermawan, Anak Agung Ngurah, I Gede Adnyana Sudibya, I Wayan Mudiartha Utama. 2012. Pengaruh Motivasi, Lingkungan Kerja, Kompetensi dan Kompensasi terhadap Kepuasan Kerja dan Kinerja Karyawan di Lingkungan Kantor Dinas Pekerjaan Umum Provinsi Bali. Journal Manajemen, Strategi Bisins dan Kewira Usaha. Vol. 6, No 2, pp. 174-184.

Dubrin, Andrews J. 2013. Leadership (Terjemahan). Edisi Kedua, PEranda Media. Jakarta

Emron Edison, Yohny Anwar, dan Imas Komariyah. 2017. Manajemen Sumber Daya Manusia. Bandung: Alfabeta.

Hasibuan, Malayu S.P. 2011. Manajemen: Dasar, Pengertian, dan Masalah. Edisi Revisi. Jakarta : Bumi Aksara

https://ldikti5.kemdikbud.go.id/home/detailpost/50-universitas-terbaik-di-indonesia-versi webometrics-2020-ui-teratas. Diakses pada tanggal 25 Desember 2020

Indonesia, R. (2003). Undang-Undang Nomor 20 Tahun 2003 tentang Sistem Pendidikan Indonesia. Indonesia.

Kartini, Kartono, 2013. Pimpinan dan Kepemimpinan. Jakarta, PT. Rajagrafindo Persada.

Kasmir. 2016. Manajemen Sumber Daya Manusia (Teori dan Praktik). Depok : PT. Rajagrafindo Persada

Kasim, D., Rantetampang, A. L., \& Lumbantobing, H. (2016). Relationships of Work Discipline, Leadership, Training, and Motivation to Performance of Employees Administration Abepura Hospital Papua 2015. International Journal of Sciences: Basic and Applied Research (IJSBAR) International Journal of Sciences: Basic and Applied Research.

Luthans, Fred. 2010. Perilaku Organisasi. Yogayakarta : Andi.

Prananta, M. I. (2008). Pengaruh Kepemimpinan dan Budaya Organisasi serta Motivasi terhadap Perilaku Kerja dan Kinerja Karyawan Hotel Berbintang di Kalimantan Timur.

Priansa, Donni Juni. 2016. Perencanaan dan Pengembangan SDM. Bandung: Alfabeta.

Robbins, \& Coulter, M. (2014). Management (12th Ed). In Prentice Hall.

Siagian, M. (2018). peranan disiplin kerja dan kompensasi dalam mendeterminasi kinerja karyawan dengan motivasi kerja sebagai variabel intervening pada pt cahaya pulau pura di kota batam. jim upb (Jurnal Ilmiah Manajemen Universitas Putera Batam). https://doi.org/10.33884/jimupb.v6i2.675

Safaria, T. 2010. Kepemimpinan. Yogyakarta : Graha 
Simanjuntak, J. Payaman. 2012. Manajemen dan Evaluasi Kinerja. Jakarta: Lembaga Penerbit Fakultas Ekonomi UI.

Smith, W. J. (2002). School Leadership and Self-Assessment: Guiding the Agenda for Change. In Second International Handbook of Educational Leadership and Administration. https://doi.org/10.1007/978-94-010-0375-9_18

Sutrisno, Edy. 2014. Manajemen Sumber Daya Manusia. Jakarta: Kencana.

Syarif. Djohan 2013. Strategi Pembinaan dan Pengembangan SDM Perguruan Tinggi Dalam meningkatkan Mutu Pendidikan Tinggi (Studi Kasus di Perguruan Tinggi di Jakarta). Jurnal Ekonomi STEI, Nomor 1, Tahun XII, Januari-Maret

Trisnaningsih, S. (2011). Faktor-faktor yang mempengaruhi kinerja dosen akutansi. Jurnal Akutansi Dan Auditing.

Wibowo, 2014. Manajemen Kinerja. Penerbit Rajawali Press, Jakarta. 